\title{
DETECTION OF TOXOPLASMA GONDII AMONG WOMEN IN DUHOK CITY-KURDISTAN REGION OF IRAQ
}

\author{
RAWA NoOri AWAD ${ }^{*}$ and Shamal ABdullah Al-MufFTI ${ }^{*}$ \\ * Dept. of Microbiology and Parasitology, College of veterinary medicine, University of Duhok, \\ Kurdistan Region-Iraq \\ ${ }^{* *}$ Dept. of Biology, College of Science, University of Duhok, Kurdistan Region-Iraq
}

(Received: May 31, 2020; Accepted for Publication: August 26, 2020)

\begin{abstract}
Background: Congenital toxoplasmosis is one of the most endemic parasitic infections that can lead to clinical complications by transmission through mother to fetus transplacentally in aborted women.

Objectives: The aim of this study was to estimate the rate of toxoplasmosis among pregnant and aborted women in Duhok/ Kurdistan Region-Iraq by using Enzyme-Linked ImmunoSorbent Assay(ELISA) and detect the seropositive cases by Real-Time Polymerase Chain Reaction (RT-PCR) .

Materials and Methods: A total of 102 samples were collected from women admitted to obstetrics and gynecology hospital in Duhok province. The data were collected through the period from January, 20 ${ }^{\text {th }}$, 2019 until December, $30^{\text {th }}, 2019$.Blood and placental samples from 60 aborted women with Bad Obstetric History $(\mathrm{BOH})$ and 42 placental samples from healthy normal pregnancies (as a control group). The placental samples of normal pregnancies were tested by RT-PCR technique while aborted women's blood and placental samples were tested by both Enzyme-Linked ImmunoSorbent Assay(ELISA) and RT-PCR techniques.

Results: The results revealed a low rate of infection by congenital toxoplasmosis. Seropositivity to $\boldsymbol{T}$. gondii were 20/60 33.3\% by ELISA, 25\% IgM, 65\% IgG and 10\% both IgG and IgM whereas the retested seropositive samples by RT-PCR only $5 \%$ showed positive results. The highest rate of infection was at 3238 age group, first trimester $85 \%$, single abortion $35 \%$, who inhibits rural area $80 \%$,ingesting homemade food $80 \%$, and contact with animals(cats) $85 \%$.

Conclusion: Real-time PCR-based technique is the most accurate and suitable for routine screening, providing a rapid, sensitive, and quantitative way of detecting congenital toxoplasmosis in clinical specimens, without any false-positive result that may help to a targeted treatment.
\end{abstract}

KEYWORDS: Toxoplasma gondii, Aborted women, ELISA, RT-PCR.

\section{INTRODUCTION}

$\mathbf{T}$ oxoplasmosis is a disease caused by parasitic protozoan used as a routine diagnosis of toxoplasmosis and early detection of infection and to prevent later newborn complications of congenital toxoplasmosis that might impose expensive costs for treatment (1).Toxoplasma gondii, one of the cosmopolitan's common parasites and the most endemic contagious agents in Iraqi aborted women (1).It is a single-cell tissue protozoan coccidian enigmatic parasite. It is an obligatory intracellular protozoan zoonotic with a heterogeneous life cycle in humans and other vertebrates (2).

Toxoplasmosis is one of the most prevalent parasitic diseases where almost one-third of the world's population is infected, approximately 25 to $30 \%$ of the world's population is infected by Toxoplasma gondii (3).On the other hand, many studies in the world and Iraq in particular, have revealed that toxoplasmosis causes recurrent abortion among pregnant women (4).

Congenital toxoplasmosis referred to a clinical state of this disease in the fetus that following an acute primary infection acquired by the mother through pregnancy (5). Although $T$. gondii infection is usually uncomplicated and asymptomatic in immunocompetent individuals, it is a potentially serious issue when acquired during pregnancy as it carries the risk transmission to the fetal in about $30 \%$ of cases and congenital toxoplasmosis may lead to manifestations varying in severity, depending on the stage of pregnancy at the time of maternal infection, most of them involving the brain and eyes (6).

shamal.al-muffti@uod.ac 
In pregnancy, the most common routes of acquiring toxoplasmosis infection are through ingesting raw or undercooked meats or contaminated water with sporulated oocysts, or direct exposure to soil or cat litter. Transfusion or organ transplantation from an infected person with toxoplasmosis can also transmit the organism $(7,8,9)$.

The gestational age at which the infection is developed is a key variable affecting the clinical fetal outcome (10).Severe toxoplasmosis occurs in immunocompromised patients that build up either acute infection or reactivation from quiescent tissue cysts (11). It can also cause symptoms similar to flu or glandular fever, sometimes including swollen lymph nodes. Once a person has had the infection they are generally thought to be protected for the rest of their lives, unless they suffer an impairment of their immune system (12).

Serological diagnostic techniques such as ELISA considered as most the commonly used approach to detect the infectious stage if it is current, recent (acute), past (chronic) (13).There are numerous diagnosis techniques but the molecular methods such as PCR amplification have been recognized as excellent and sensitive techniques to diagnose congenital toxoplasmosis in immunodeficient patients in much reduced time(14). Most researchers have used the $B 1$ gene for detection $T$. gondii in a variety of biological samples (15).The technique can identify tachyzoites in amniotic fluid (AF), placenta, and cord blood (16).

Serological recognition of specific antiToxoplasma immunoglobulin is a primarily serological technique to detect $T$. gondii infection varies in sensitivity and specificity depending on commercially obtainable serologic kits which may fail to detect infection, particularly in some immunocompromised patients (17). A recent study in Iraq showed that detection of $T$. gondii by molecular methods RTPCR is crucial for diagnosing congenital toxoplasmosis. Real-time PCR can be used as an additional diagnostic tool for the rapid accurate detection of $T$. gondii in various clinical materials such as the placenta (4).

\section{MATERIALS AND METHODS}

A total of 102 samples were collected from all patients under sterilized conditions to prevent any possible contamination. Out of these 102 cases in ranged age 18-45 years, 42 placentas were collected from full-term normal pregnancies have been chosen randomly as a control group, while the other 60 placentas and blood samples were collected from aborted women with $\mathrm{BOH}$ and spontaneous miscarriage. All were attending Duhok Gynecology and Obstetrics Hospital. From each patient, $50 \mathrm{mg}$ of placental tissue soaked with Phosphate Buffered Saline (PBS) buffer Then samples will be stored at $-20 \mathrm{C}$ until be used for DNA extraction by using QIAamp DNA tissue Kit from QIAgen Inc. Hilden, Germany, Catalog No. 51306 while $3 \mathrm{ml}$ venous blood samples from aborted women only by using sterile disposable hypodermic vacationer needles and tubes. Venous blood centrifuged at $14,000 \mathrm{rpm}$ for $20 \mathrm{~min}$ to obtain serum and stored at $-20^{\circ} \mathrm{C}$ until use. A questionnaire-based on personal information was prepared, to obtain the important factor(s) effect on the epidemiology of the Toxoplasma gondii containing all required variables for data analysis. IgM and IgG anti- $T$. gondii antibodies were detected in serum samples of aborted women by using ELISA kit Bioactiva Diagnostica, Germany. While placentas were tested by using RT-PCR Ecoli Toxoplasma gondii kit, Russia and Toxoplasma gondii RTPCR kit, Anatolia gene works, Turkey.

\section{Statistical Analysis:}

Data were analyzed using SPSS program version 18 . Results with $P$-value 0.05 was considered to be statistically significant. Chi square test was used to indicate the agreement of studied parameters and tests.

\section{RESULTS}

The results of the current study revealed that aborted women were at low rates of infection by congenital toxoplasmosis. Table. 1 demonstrates the participated groups of all 102 females that were enrolled for this study. 
Table (1): Variables that affect the epidemiology of the Toxoplasma gondii among Women in Duhok province.

\begin{tabular}{|c|c|c|c|c|c|c|c|}
\hline \multirow{2}{*}{$\begin{array}{l}\text { Examined groups } \\
\text { variables }\end{array}$} & \multirow[t]{2}{*}{ Groups } & \multicolumn{2}{|c|}{ Aborted women } & \multicolumn{2}{|c|}{ Pregnant women } & \multicolumn{2}{|c|}{ Total } \\
\hline & & $\mathrm{N}=60$ & $\%$ & $\mathrm{~N}=42$ & $\%$ & $\mathrm{~N}=102$ & $\%$ \\
\hline \multirow[t]{4}{*}{ Age (year) } & $18-24$ & 23 & 38.3 & 13 & 30.95 & 36 & 35.3 \\
\hline & $25-31$ & 16 & 26.7 & 20 & 47.6 & 36 & 35.3 \\
\hline & $32-38$ & 18 & 30 & 8 & 19.05 & 26 & 25.3 \\
\hline & $39-45$ & 3 & 5 & 1 & 2.4 & 4 & 3.9 \\
\hline \multirow[t]{2}{*}{ Residency } & Urban & 16 & 26.7 & 15 & 35.7 & 31 & 30.4 \\
\hline & Rural & 44 & 73.3 & 27 & 64.3 & 71 & 69.6 \\
\hline \multirow[t]{2}{*}{ Occupation } & Employed & 3 & 5 & 5 & 11.9 & 8 & 7.8 \\
\hline & House wife & 57 & 95 & 37 & 88.1 & 94 & 92.2 \\
\hline \multirow[t]{2}{*}{ Educational level } & Literate & 31 & 51.7 & 25 & 59.5 & 56 & 54.9 \\
\hline & Illiterate & 29 & 48.3 & 17 & 40.5 & 46 & 45.1 \\
\hline \multirow{5}{*}{$\begin{array}{c}\text { Number of previous } \\
\text { pregnancies }\end{array}$} & None & 12 & 20 & 16 & 38.1 & 28 & 27.5 \\
\hline & $\mathrm{P} 1$ & 10 & 16.7 & 7 & 16.7 & 17 & 16.7 \\
\hline & P2 & 13 & 21.7 & 4 & 9.5 & 17 & 16.7 \\
\hline & P3 & 10 & 16.7 & 5 & 11.9 & 15 & 14.7 \\
\hline & P4 and more & 15 & 25 & 10 & 23.8 & 25 & 24.5 \\
\hline \multirow{4}{*}{$\begin{array}{l}\text { Number of previous } \\
\text { abortions }\end{array}$} & $\mathrm{A} 1$ & 38 & 63.3 & 38 & 90.5 & 76 & 74.5 \\
\hline & $\mathrm{A} 2$ & 11 & 18.3 & 2 & 4.8 & 13 & 12.7 \\
\hline & $\mathrm{A} 3$ & 3 & 5 & 1 & 2.4 & 4 & 3.9 \\
\hline & A4 and more & 8 & 13.3 & 1 & 2.4 & 9 & 8.8 \\
\hline \multirow[t]{3}{*}{ Gestational age } & $\mathrm{T} 1$ & 40 & 66.7 & - & - & 40 & 39.2 \\
\hline & $\mathrm{T} 2$ & 18 & 30 & - & - & 18 & 17.6 \\
\hline & T3 & 2 & 3.3 & 42 & 100 & 44 & 43.1 \\
\hline \multirow{2}{*}{$\begin{array}{l}\text { Repeated abortion } \\
\text { consecutive }\end{array}$} & yes & 60 & 100 & 4 & 9.5 & 64 & 62.7 \\
\hline & No & - & - & 38 & 90.5 & 38 & 37.3 \\
\hline \multirow{2}{*}{$\begin{array}{l}\text { Previously diagnosed for } \\
\text { toxoplasmosis }\end{array}$} & Yes & 7 & 11.7 & 3 & 7.1 & 10 & 9.8 \\
\hline & No & 53 & 88.3 & 39 & 92.9 & 92 & 90.2 \\
\hline \multirow{2}{*}{$\begin{array}{l}\text { Previously treated for } \\
\text { toxoplasmosis }\end{array}$} & Yes & 7 & 11.7 & 3 & 7.1 & 10 & 9.8 \\
\hline & No & 53 & 88.3 & 39 & 92.9 & 92 & 90.2 \\
\hline \multirow{2}{*}{$\begin{array}{l}\text { Are there any congenital } \\
\text { abnormalities in fetus }\end{array}$} & Yes & 7 & 11.7 & 1 & 2.4 & 8 & 7.8 \\
\hline & No & 53 & 88.3 & 41 & 97.6 & 94 & 92.2 \\
\hline \multirow[t]{2}{*}{ Contact with cats } & Yes & 34 & 56.7 & 6 & 14.3 & 40 & 39.2 \\
\hline & No & 26 & 43.3 & 36 & 85.7 & 62 & 60.8 \\
\hline \multirow[t]{2}{*}{ Food habit } & Homemade & 51 & 85 & 32 & 76.2 & 83 & 81.4 \\
\hline & Restaurant & 8 & 13.3 & 5 & 11.9 & 13 & 12.7 \\
\hline
\end{tabular}


Journal of University of Duhok., Vol. 23, No.2 (Agri. and Vet. Sciences), Pp 20-33, 2020

\begin{tabular}{cccccccc}
\hline & Vegetarian & 1 & 1.7 & 5 & 11.9 & 6 & 5.9 \\
\hline \multirow{2}{*}{ Family size } & $1-5$ & 12 & 20 & - & - & 12 & 11.8 \\
\cline { 2 - 7 } & $5-10$ & 48 & 80 & 4 & 9.5 & 52 & 50.9 \\
\cline { 2 - 7 } & 11 and more & - & - & 38 & 90.5 & 38 & 37.3 \\
\hline \multirow{2}{*}{$\begin{array}{c}\text { Pre-existing medical } \\
\text { disease }\end{array}$} & Diabetes & 2 & 3.3 & 2 & 4.8 & 4 & 3.9 \\
\cline { 2 - 7 } & B.P & 3 & 5 & 3 & 7.1 & 6 & 5.9 \\
\cline { 2 - 7 } & None & 55 & 91.7 & 37 & 88.1 & 92 & 90.2 \\
\hline \multirow{2}{*}{\begin{tabular}{c} 
Uterine abnormalities \\
\cline { 2 - 7 } disease
\end{tabular}} & Yes & 11 & 18.3 & 7 & 16.7 & 18 & 17.6 \\
\hline & No & 49 & 81.7 & 35 & 83.3 & 84 & 82.4 \\
\hline & Diabetes & 25 & 41.7 & 10 & 23.8 & 35 & 34.3 \\
\cline { 2 - 7 } & B.P & 16 & 26.7 & 6 & 14.3 & 22 & 21.6 \\
\hline
\end{tabular}

Forty-two (41.2\%) placental samples collected from control married women with no bad obstetric history were examined by Realtime PCR technique after DNA extraction to detect Toxoplasma gondii. All control samples showed negative results. While the other 60 samples (58.8\%) (Blood and placentas) have had bad obstetric history early or later in their pregnancy with single or recurrent consecutive abortions. Serum samples were examined by the ELISA technique as a primary diagnostic test. Serum of 20(33.3\%) aborted women showed seropositive results referred to a higher seroprevalence of anti-Toxoplasma IgG than IgM antibodies, 25\% (5/20) were IgM antibodies and $65 \%(13 / 20)$ were IgG antibodies, only 2 cases (10\%) were both IgM and IgG antibodies respectively
(Table
2).

Table (2): Distribution of studied groups according to the anti-Toxoplasma antibodies using ELISA.

\begin{tabular}{|c|c|c|c|c|c|c|c|c|c|}
\hline \multirow[t]{2}{*}{ Test } & \multicolumn{4}{|c|}{ Seropositive samples } & \multicolumn{4}{|c|}{ Seronegative samples } & \multirow{2}{*}{$\begin{array}{c}\text { Total } \\
\text { Examined } \\
\text { Aborted } \\
\text { women } \\
\end{array}$} \\
\hline & $\lg M$ & $\lg G$ & $\lg G \& \lg M$ & Total & $\lg M$ & $\lg G$ & $\lg G \& \lg M$ & Total & \\
\hline ELISA & 5 & 13 & 2 & 20 & 55 & 47 & 58 & 40 & 60 \\
\hline$\%$ & 25 & 65 & 10 & 100 & 91.7 & 78.3 & 96.7 & 66.7 & 100 \\
\hline
\end{tabular}

Based on the finding of the current study, this result showed the highest rate of toxoplasmosis IgG antibodies $60 \%$ was recorded at the age group 32-38 years old patients by ELISA. The lowest rate of infection was $5 \%$ in the age group 18-24 years of old patients (Table 3).

Table (3): Detection of toxoplasmosis using ELISA among aborted women in according to age.

\begin{tabular}{ccccccc}
\hline Age (year) & $\begin{array}{c}\text { No. of Non Infected Aborted } \\
\text { women }\end{array}$ & No. of Infected Aborted women & $\begin{array}{c}\text { Total No. of examined Aborted } \\
\text { women }\end{array}$ \\
\hline $18-24$ & 22 & $55 \%$ & 1 & $5 \%$ & 23 & $38.3 \%$ \\
\hline $25-31$ & 12 & $30 \%$ & 4 & $20 \%$ & 16 & $26.7 \%$ \\
\hline $32-38$ & 6 & $15 \%$ & 12 & $60 \%$ & 18 & $30 \%$ \\
\hline $39-45$ & 0 & $0 \%$ & 3 & $15 \%$ & 3 & $5 \%$ \\
\hline Total & 40 & $66.7 \%$ & 20 & $33.3 \%$ & 60 & $100 \%$ \\
\hline$\left(\chi^{2}\right)=24.196($ Significant) $, d f=3, p$ value $=0.00003$ & & & &
\end{tabular}


Also, the results showed the toxoplasmosis in women who lived in rural areas $80 \%$ was higher than urban area $20 \%$ (Figure 1).

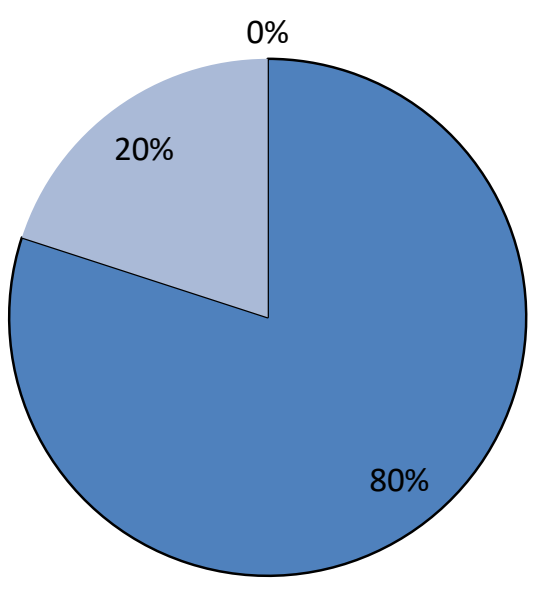

Fig. (1): ELISA test detection of congenital toxoplasmosis among aborted women in relation to residence area

It was found that all anti-Toxoplasma $\operatorname{IgG}$ and IgM antibodies in aborted women were housewives. According to food habits, aborted women who depend on homemade food showed higher seropositive results $80 \%$ while none at vegetarians. (Table

Table (4): Detection of toxoplasmosis using ELISA among aborted women according to food habit.

\begin{tabular}{|c|c|c|c|c|c|c|c|c|c|}
\hline \multirow[t]{3}{*}{ Food habit } & \multicolumn{2}{|c|}{$\begin{array}{c}\text { Seronegative } \\
\text { samples }\end{array}$} & \multicolumn{2}{|c|}{$\begin{array}{l}\text { Seropositive } \\
\text { samples }\end{array}$} & \multicolumn{2}{|c|}{ Total Examined Aborted women } & \multicolumn{3}{|c|}{ Statistics } \\
\hline & & & & & & & $\mathrm{X}^{2}$ Test & $d f$ & $p$-value \\
\hline & NO. & $\%$ & NO. & $\%$ & NO. & $\%$ & & & \\
\hline Homemade & 35 & 87.5 & 16 & 80 & 51 & 85 & & & \\
\hline Restaurants & 4 & 10 & 4 & 20 & 8 & 13.3 & 1.588 & 2 & 0.45 \\
\hline Vegetarian & 1 & 2.5 & 0 & 0 & 1 & 1.7 & & & \\
\hline Total & 40 & 66.7 & 20 & 33.3 & 60 & 100 & No & anif & ant \\
\hline
\end{tabular}

The toxoplasmosis in illiterate aborted women $70 \%$ was higher than literate $30 \%$. (Table 5)

Table (5): Detection of toxoplasmosis using ELISA among aborted women according to educational level.

\begin{tabular}{|c|c|c|c|c|c|c|c|c|c|}
\hline \multirow[t]{3}{*}{ Educational level } & \multicolumn{2}{|c|}{$\begin{array}{l}\text { Seronegative } \\
\text { samples }\end{array}$} & \multicolumn{2}{|c|}{$\begin{array}{l}\text { Seropositive } \\
\text { samples }\end{array}$} & \multicolumn{2}{|c|}{$\begin{array}{l}\text { Total Examined Aborted } \\
\text { women }\end{array}$} & \multicolumn{3}{|c|}{ Statistics } \\
\hline & & & & & & & \multirow[t]{3}{*}{$\mathrm{X}^{2}$ Test } & \multirow[t]{3}{*}{$d f$} & \multirow[t]{3}{*}{$p$-value } \\
\hline & No. & $\%$ & No. & $\%$ & NO. & $\%$ & & & \\
\hline Literate & 25 & $62.5 \%$ & 6 & $30 \%$ & 31 & $51.7 \%$ & & & \\
\hline Illiterate & 15 & $37.5 \%$ & 14 & $70 \%$ & 29 & $48.3 \%$ & 5.6396 & 1 & 0.0176 \\
\hline Total & 40 & $66.7 \%$ & 20 & $33.3 \%$ & 60 & $100 \%$ & \multicolumn{3}{|c|}{ Significant } \\
\hline
\end{tabular}

This study showed that the highest rate of toxoplasmosis IgG antibodies were in women with 4 previous pregnancies and more
$55 \%$. Whereas, all aborted women with no kids were seronegative. (Table 6) shamal.al-muffti@uod.ac 
Table (6): Detection of congenital toxoplasmosis using ELISA among aborted women according to the frequency of previous pregnancies.

\begin{tabular}{|c|c|c|c|c|c|c|c|c|c|}
\hline \multirow{3}{*}{$\begin{array}{c}\text { Number of } \\
\text { previous } \\
\text { pregnancies }\end{array}$} & \multicolumn{2}{|c|}{$\begin{array}{c}\text { Seronegative } \\
\text { samples }\end{array}$} & \multicolumn{2}{|c|}{$\begin{array}{c}\text { Seropositive } \\
\text { samples }\end{array}$} & \multicolumn{2}{|c|}{ Total Examined Aborted women } & \multicolumn{3}{|c|}{ Statistics } \\
\hline & & & & & & & $\mathrm{x}^{2}$ Test & $d f$ & $p$-value \\
\hline & NO. & $\%$ & No. & $\%$ & No. & $\%$ & & & \\
\hline None & 12 & 30 & 0 & 0 & 12 & 20 & & & \\
\hline Once & 9 & 22.5 & 1 & 5 & 10 & 16.7 & & & \\
\hline Twice & 8 & 20 & 5 & 25 & 13 & 21.7 & 19.454 & 4 & 0.0006 \\
\hline Triple & 7 & 17.5 & 3 & 15 & 10 & 16.7 & & & \\
\hline Four and More & 4 & 10 & 11 & 55 & 15 & 25 & & & \\
\hline Total & 40 & 66.7 & 20 & 33.3 & 60 & 100 & & nific & \\
\hline
\end{tabular}

Results revealed that aborted women with single $35 \%$, four abortions and more $35 \%$ have the highest level of anti-Toxoplasma antibodies and lower levels in aborted women with double $20 \%$ and triple 10\%abortions (Table 7).

Table (7): Detection of toxoplasmosis using ELISA among aborted women according to the frequency of previous abortions.

\begin{tabular}{|c|c|c|c|c|c|c|c|c|c|}
\hline \multirow[t]{3}{*}{$\begin{array}{l}\text { Number of previous } \\
\text { abortions }\end{array}$} & \multicolumn{2}{|c|}{$\begin{array}{l}\text { Seronegative } \\
\text { samples }\end{array}$} & \multicolumn{2}{|c|}{$\begin{array}{l}\text { Seropositive } \\
\text { samples }\end{array}$} & \multicolumn{2}{|c|}{$\begin{array}{c}\text { Total Examined Aborted } \\
\text { women }\end{array}$} & \multicolumn{3}{|c|}{ Statistics } \\
\hline & & & & & & & $\mathrm{X}^{2}$ Test & $d f$ & $p$-value \\
\hline & No. & $\%$ & No. & $\%$ & No. & $\%$ & & & \\
\hline Once & 31 & 77.5 & 7 & 35 & 38 & 63.3 & & & \\
\hline Twice & 7 & 17.5 & 4 & 20 & 11 & 18.3 & 15.911 & 3 & 0.0012 \\
\hline Triple & 1 & 2.5 & 2 & 10 & 3 & 5 & & & \\
\hline four and more & 1 & 2.5 & 7 & 35 & 8 & 13.3 & & & \\
\hline Total & 40 & 66.7 & 20 & 33.3 & 60 & 100 & & nific & \\
\hline
\end{tabular}

The highest rate of infection $85 \%$ was at first trimester gestational age aborted women,
$15 \%$ second trimester and none in the third trimester.
(Table

Table (8): Detection of toxoplasmosis using ELISA among aborted women in according to gestational age.

\begin{tabular}{|c|c|c|c|c|c|c|c|c|c|}
\hline \multirow[t]{3}{*}{ Gestational age } & \multicolumn{2}{|c|}{$\begin{array}{l}\text { Seronegative } \\
\text { samples }\end{array}$} & \multicolumn{2}{|c|}{$\begin{array}{l}\text { Seropositive } \\
\text { samples }\end{array}$} & \multicolumn{2}{|c|}{$\begin{array}{c}\text { Total Examined Aborted } \\
\text { women }\end{array}$} & \multicolumn{3}{|c|}{ Statistics } \\
\hline & & & & & & & $\mathrm{X}^{2}$ Test & $d f$ & $p$-value \\
\hline & NO. & $\%$ & No. & $\%$ & NO. & $\%$ & & & \\
\hline T1 & 23 & $57.5 \%$ & 17 & $85 \%$ & 40 & $66.7 \%$ & & & \\
\hline T2 & 15 & $37.5 \%$ & 3 & $15 \%$ & 18 & $30 \%$ & 4.7625 & 2 & 0.0924 \\
\hline T3 & 2 & $5 \%$ & 0 & $0 \%$ & 2 & $3.3 \%$ & & & \\
\hline Total & 40 & $66.7 \%$ & 20 & $33.3 \%$ & 60 & $100 \%$ & & gnif & \\
\hline
\end{tabular}

Showed low results $30 \%$ at those who were previously diagnosed and treated for toxoplasmosis. (Table 9). 
Table (9): Detection of toxoplasmosis using ELISA among aborted women in according to the treatment.

\begin{tabular}{|c|c|c|c|c|c|c|c|c|c|}
\hline \multirow[t]{3}{*}{$\begin{array}{l}\text { Previously treated for } \\
\text { toxoplasmosis }\end{array}$} & \multicolumn{2}{|c|}{$\begin{array}{l}\text { Seronegative } \\
\text { samples }\end{array}$} & \multicolumn{2}{|c|}{$\begin{array}{l}\text { Seropositive } \\
\text { samples }\end{array}$} & \multicolumn{2}{|c|}{$\begin{array}{l}\text { Total Examined } \\
\text { Aborted women }\end{array}$} & \multicolumn{3}{|c|}{ Statistics } \\
\hline & & & & & & & \multirow[t]{3}{*}{$\mathrm{X}^{2}$ Test } & \multirow[t]{3}{*}{$d f$} & \multirow[t]{3}{*}{$p$-value } \\
\hline & No. & $\%$ & No. & $\%$ & No. & $\%$ & & & \\
\hline Yes & 1 & 2.5 & 6 & 30 & 7 & 11.7 & & & \\
\hline No & 39 & 97.5 & 14 & 70 & 53 & 88.3 & 9.7844 & 1 & 0.002 \\
\hline Total & 40 & 66.7 & 20 & 33.3 & 60 & 100 & \multicolumn{3}{|c|}{ Significant } \\
\hline
\end{tabular}

High rates at those who showed congenital abnormalities were (6/7) cases30\% in their fetus.(Table 10)

Table (10): Detection of toxoplasmosis using ELIS A among aborted womenaccording to congenital abnormalities in the fetus.

\begin{tabular}{|c|c|c|c|c|c|c|c|c|c|}
\hline \multirow[t]{3}{*}{$\begin{array}{c}\text { Congenital abnormalities in } \\
\text { the fetus }\end{array}$} & \multicolumn{2}{|c|}{$\begin{array}{l}\text { Seronegative } \\
\text { samples }\end{array}$} & \multicolumn{2}{|c|}{$\begin{array}{l}\text { Seropositive } \\
\text { samples }\end{array}$} & \multicolumn{2}{|c|}{$\begin{array}{c}\text { Total Examined Aborted } \\
\text { women }\end{array}$} & \multicolumn{3}{|c|}{ Statistics } \\
\hline & & & & & & & \multirow[t]{3}{*}{$\mathrm{X}^{2}$ Test } & \multirow[t]{3}{*}{$d f$} & \multirow[t]{3}{*}{$p$-value } \\
\hline & No. & $\%$ & No. & $\%$ & No. & $\%$ & & & \\
\hline Yes & 1 & 2.5 & 6 & 30 & 7 & 11.7 & & & \\
\hline No & 39 & 97.5 & 14 & 70 & 53 & 88.3 & 9.7844 & 1 & 0.002 \\
\hline Total & 40 & 66.7 & 20 & 33.3 & 60 & 100 & \multicolumn{3}{|c|}{ Significant } \\
\hline
\end{tabular}

The current study showed a significant difference in seropositivity at those who have direct contact with cats $85 \%$. (Table 11)

Table (11): Detection of toxoplasmosis using ELISA among aborted women according to contact with animals.

\begin{tabular}{|c|c|c|c|c|c|c|c|c|c|}
\hline \multirow[t]{3}{*}{$\begin{array}{l}\text { Contact with } \\
\text { animals }\end{array}$} & \multicolumn{2}{|c|}{$\begin{array}{l}\text { Seronegative } \\
\text { samples }\end{array}$} & \multicolumn{2}{|c|}{$\begin{array}{l}\text { Seropositive } \\
\text { samples }\end{array}$} & \multicolumn{2}{|c|}{$\begin{array}{c}\text { Total Examined Aborted } \\
\text { women }\end{array}$} & \multicolumn{3}{|c|}{ Statistics } \\
\hline & & & & & & & \multirow[t]{3}{*}{$\mathrm{X}^{2}$ Test } & \multirow[t]{3}{*}{$d f$} & \multirow[t]{3}{*}{$p$-value } \\
\hline & No. & $\%$ & No. & $\%$ & No. & $\%$ & & & \\
\hline Contact & 17 & 42.5 & 17 & 85 & 34 & 56.7 & & & \\
\hline No contact & 23 & 57.5 & 3 & 15 & 26 & 43.3 & 9.8077 & 1 & 0.002 \\
\hline Total & 40 & 66.7 & 20 & 33.3 & 60 & 100 & \multicolumn{3}{|c|}{ Significant } \\
\hline
\end{tabular}

According to family size aborted women who have1-5memberfamilies gave low seropositive results $5 \%$ while the highest was in 5-10, 95\% member families, and none seropositive cases with aborted women of two member families (Table

12). 
Table (12): Detection of toxoplasmosis using ELISA among aborted women according to family size.

\begin{tabular}{|c|c|c|c|c|c|c|c|c|c|}
\hline \multirow[t]{3}{*}{ Family size } & \multicolumn{2}{|c|}{$\begin{array}{l}\text { seronegative } \\
\text { samples }\end{array}$} & \multicolumn{2}{|c|}{$\begin{array}{l}\text { seropositive } \\
\text { samples }\end{array}$} & \multicolumn{2}{|c|}{$\begin{array}{c}\text { Total Examined Aborted } \\
\text { women }\end{array}$} & \multicolumn{3}{|c|}{ Statistics } \\
\hline & & & & & & & \multirow[t]{2}{*}{$\mathrm{X}^{2}$ Test } & \multirow[t]{2}{*}{$d f$} & \multirow[t]{2}{*}{$p$-value } \\
\hline & No. & $\%$ & NO. & $\%$ & No. & $\%$ & & & \\
\hline 1-5 members & 11 & 27.5 & 1 & 5 & 12 & 20 & & & \\
\hline 5-10 members & 29 & 72.5 & 19 & 95 & 48 & 80 & 4.2188 & 1 & 0.04 \\
\hline 11 and more & 0 & 0 & 0 & 0 & 0 & 0 & & & \\
\hline Total & 40 & 66.7 & 20 & 33.3 & 60 & 100 & & ific & \\
\hline
\end{tabular}

All 20 seropositive ELISA cases were retested by a real-time PCR technique. Out of 20 cases, only one case $5 \%$ showed positive results for both tests (ELISA IgM and IgG, RTPCR),(Table 13)who's 32 years old live in camps uneducated housewife, with two children and four previous consecutive abortions, aborted her two months fetus with congenital abnormalities (Hydrocephaly) due to congenital toxoplasmosis. Also, this case lived in family consists of four members, has direct contact with cats, and depends on homemade food, with no medical history and uterine abnormalities.

Table13: Distribution of studied groups according to the anti-Toxoplasma antibodies and RT-PCR.

\begin{tabular}{|c|c|c|c|c|c|c|c|c|c|}
\hline \multirow[t]{2}{*}{ Test } & \multicolumn{2}{|c|}{ Positive samples } & \multicolumn{2}{|c|}{ Negative samples } & \multicolumn{2}{|c|}{ Total } & \multicolumn{3}{|c|}{ Statistics } \\
\hline & NO. & $\%$ & NO. & $\%$ & NO. & $\%$ & $\mathrm{X}^{2}$ Test & $d f$ & $p$-value \\
\hline ELISA & 20 & 95.3 & 40 & 39.6 & 60 & 49.2 & 21.53 & 1 & 0.000003 \\
\hline \multirow[t]{2}{*}{ RT-PCR } & 1 & 4.8 & 61 & 60.4 & 62 & 50.8 & & & \\
\hline & & & & & & & \multicolumn{3}{|c|}{ Significant } \\
\hline
\end{tabular}

\section{DISCUSSION}

In the past five years, many researchers in Iraq and Kurdistan particularly conducted many diagnostic techniques for early detecting of congenital toxoplasmosis in pregnant and aborted women and applying the most recent tests and procedures to reach no doubted results, includes many serological and molecular techniques. The traditional diagnosis of congenital toxoplasmosis usually depends on serological tests such as ELISA that has many limitations of detection (18).

Real-time PCR which is the best-performing accurate technique till now that has been described as a modern high sensitive assay for early detection of minimal amounts of parasitic DNA and latent infection, produces the quantitative results in different types of samples such as blood and placental tissue (19).

In the present study, all control samples 41.2\% were tested by Real-Time PCR and showed negative results. They were completely clear of Toxoplasma gondii DNA. Aborted BOH $58.8 \%$ blood samples were tested by ECLIA, $33.3 \%$ of cases were seropositive to different antibodies. 25\%were IgM seropositive referring to recent acute congenital toxoplasmosis infection and $65 \%$ were higher IgG seropositive than IgM referring to latent chronic infection and presence of tissue cyst, only two cases $10 \%$ were both IgM and IgG seropositive. Detection by ELISA technique helps to differentiate time of infection by detection IgM antibodies (rise in one or two weeks), While IgG antibodies referred to the previous infection has happened already but does not tell if it is recent and past or latent infection (4).Based on our findings, results revealed that aborted women under age 25 age of higher fertility 5\% seem less to have congenital toxoplasmosis (CT) while showing a high prevalence of $60 \%$ of this parasitemia among 32-38 age group showing a significant difference. Also, this indicates that the infection 
getting increased by age, older age more exposure, our results were in agreement with a previous study in Thi Qar (1), And another study in Duhok province, that showed higher seropositivity in aborted women over 30 years old(20), And acquiring congenital toxoplasmosis in the 25-31 age group was more than other ages (21), And disagree with a study in Babylon revealed high prevalence in aborted women at the age group of 21-25 (5).

Toxoplasmosis infection in patients who lived in rural areas $80 \%$ was higher than urban area $20 \%$. This result leads to a significant correlation in the location of residency and congenital toxoplasmosis infection. Our findings may due to low-temperature weather and low humidity that minimize the survival of oocysts and then minimizing the probability of transmission and reduce the infection titers to the lowest. A study in the United Kingdome reported that toxoplasmosis infection was higher in rural areas than urban as by this study (22).A contrary study in Iran reported that higher prevalence was in urban areas and city dwellers(23).

According to our study, all toxoplasmosis $\mathrm{IgG}$ and $\mathrm{IgM}$ seropositive aborted women were housewives whom their natural habits mostly depend on homemade food and restaurants $80 \%$, $20 \%$ respectively, while all-vegetarian aborted and pregnant women showed negative results. We observed that congenital toxoplasmosis infection associated with ingestion of undercooked and cured meat as a basic infectious risk factor, our findings were consistent with another study in England that found an association between toxoplasmosis and consumption of raw meat(24).Toxoplasma gondii has been recognized as the foodborne pathogen connected with the second-highest public health impact both in the USA and Netherlands, and this supporting our study(25),(26), our findings were in contrast with a study performed in Iran that showed there is no relationship between ingestion the raw meat and toxoplasmosis infection(23).

The toxoplasmosis infection in illiterate aborted women was higher than literate in relation to hygienic consideration and awareness, $70 \%, 30 \%$ respectively; showing the significant relationship of Toxoplasma gondii infection and education, our study was consistent with a study conducted in Iran(27).This study showed no significant relationship in the number of children and toxoplasmosis infection, that the highest rate of toxoplasmosis IgG seropositive were in women with four previous pregnancies $55 \%$ and more referring to a previous infection, while all aborted women with no kids were negative.

One of our important findings, there was a significant relationship between the number of previous abortions and congenital toxoplasmosis, revealed that the highest rate of congenital Toxoplasmosis was at women with single $35 \%$ and four abortions and more $35 \%$, and lower levels in aborted women with double $20 \%$ and triple $10 \%$ abortions, might lead to recurrent abortions. Our study when in contrast with a study conducted in Babylon that suggested that toxoplasmosis doesn't cause recurrent abortion(5), While it was confirming Darweesh et al.,(4) study that reported percentage of infection related to a number of abortions.

Toxoplasmosis infected abortions were recorded the highest in the first trimester $85 \%, 15 \%$ second trimester and none in the third trimester because Toxoplasma gondii Tachyzoites will attack embryo at embryogenesis leading to miscarriage of fetus. Our result was in contrast with a study conducted in Ethiopia were the highest rates in the third trimester(28), But in agreement with another study in Saudi Arabia(29)

Seropositivity of aborted women who showed congenital abnormalities were $6 / 7$ cases $30 \%$ in their fetus, referring to serious consequences affecting the fetus caused by congenital toxoplasmosis infection. Showed low results $30 \%$ at those who were previously diagnosed and treated for toxoplasmosis. These seropositive results may due to less effective treatment. Our study showed a significant difference in seropositivity at those who have direct contact with animals $85 \%$, cats especially because they are the definitive host sheds the oocysts. We found that cats and birds like chicken were associated with toxoplasmosis infection. Our study came in agreement with an Ethiopian study that was done in 2016(30), and it was inconsistent with another study conducted in Mexico(31).According to family size aborted women who have 1-5 member families gave low positive results $5 \%$ while the highest was in 5$10,95 \%$ members families and none positive 
cases with aborted women of two-member families but we didn't find any relation between family size and toxoplasmosis infection.

Since serological testing has been one of the major diagnostic techniques for toxoplasmosis but it has many limitations and almost fails and gives false-positive results. Real-time PCR technique was used to confirm the diagnosis by detection B1 gene of Toxoplasma gondii DNA in placental tissue samples of aborted women. B1 gene, although of unknown function, is mostly utilized in a variety of diagnostic and epidemiological researches thanks to its specificity and sensitivity (32).

All 20 seropositive ELISA cases were tested by Real-Time PCR technique. Out of 20 cases, only $5 \%$ showed positive results as in Figure.2, for both tests (ELISA IgM and IgG, RT-PCR), who's 32 years old live in camps uneducated housewife, with two children and four previous consecutive abortions, aborted her two months fetus with congenital abnormalities (Hydrocephaly) due to congenital toxoplasmosis parasitemia. Also, this case lived in family consists of four members, has direct contact with animals (cats), and depends on homemade food, with no medical history and uterine abnormalities. Our study was inconsistent with AL-Dujaily et al. who used both ELISA and RTPCR techniques as a confirmatory tool (33).

Our study was in agreement with Darweesh et al., (4) in Diyala/Iraq and Mousavi et al., (19) in Iran that reported 2 positive cases by RT-PCR who were seropositive for both IgG and IgM by ELISA test. According to our results, a key point should be noticed, 19 seropositive cases showed negative results by the RT-PCR test, this clears the fact that the RT-PCR technique is the highest in sensitivity till now.

Real-time PCR assay as a sensitive accurate diagnostic tool provides an early approach for molecular detection of the acute and chronic phases of infection in clinical samples without any false-positive result that may help to a targeted treatment. Also, this method may be appropriate for screening of $T$. gondii infection in special cases such as immunocompromised groups who usually fail to produce specific IgM or increased IgG titers(19).We conclude RTPCR methods in aborted women were the best diagnostic technique in detecting the recent and reactive and latent infection by $T$. gondii.
The promising results described in this study lead to the fact that, in the past 5 years due to the increase of pregnant women's awareness and strength of health educational programs we reduced to the minimal number of congenital toxoplasmosis cases in Duhok province.

\section{REFERENCES}

Alaa M., Sukaina R., Neamah, Noor K. (2019). Seroepidemiological study on Toxoplasma gondii of aborted women at AL- Shatrah hospital of AL- Shatrah district/ThiQar city, Iraq. Journal of Kerbala University; 17(3):4551.

Al-Hindi A., Lubbad A. (2009). Seroprevalence of toxoplasmosis among Palestinian aborted women in Gaza. Annals of Alquds medicine; 5: 39-47.

Abdoli A., Dalimi A., Soltanghoraee H., Ghaffarifar F. (2017). Molecular and genotypic characterization of Toxoplasma gondii in paraffin-embedded fetoplacental tissues of women with recurrent spontaneous abortion.

International Journal of Fertility and Sterility; 10:327-336.

Darweesh N., Hussein R., Salman S., Shaker M. (2018). Immunological and Molecular study of Toxoplasma gondii from aborted women in Diyala, Iraq. Scientific Journal of Medical Research; 2(6):75-82.

Mohammed L., Al-Janabi MS. (2019). Seroprevalence of toxoplasmosis in aborted women in Babylon province, Iraq. Medical Journal of Babylon; 16:188-91.

Robert F., Dupretz P., Yvenou C., Quinio D., Poulain P., Guiguen C., et al. (2010). Clinical relevance of placenta examination for the diagnosis of congenital toxoplasmosis. Pediatric Infectious Disease Journal; 29(1):33-8.

Hussein S., Elshemy A., Abdelmawgod M., Mohammed A. (2017). Seroprevalence of Toxoplasma gondii among primigravida women and their neonates in Sohag governorate, Egypt. Journal of the Egyptian Society of Parasitology; 47, 381-388. 
Pinon J., Dumon H., Chemla C., Franck J., Petersen E., et al. (2001). Strategy for diagnosis of congenital toxoplasmosis: evaluation of methods comparing mothers and newborns and standard methods for postnatal detection of immunoglobulin G, M, and A antibody. Journal of Clinical Microbiology; 39: 22672271.

Rorman E., Zamir C., Rilkis I., Ben-David H. (2006). Congenital toxoplasmosis prenatal aspects of Toxoplasma gondii infection. Journal of Reproductive Toxicology; 21: 458-472.

Mohammed T. (2011). Seroprevalence of Toxoplasma gondii among pregnant women in Baghdad city, Iraq. Iraqi Academic Scientific Journal; 24:21-28.

Ajzenberg D., Yera H., Marty P., Paris L., Dalle F., et al. (2015). Genotype of 88 Toxoplasma gondii Isolates Associated with Toxoplasmosis in Immunocompromised Patients and Correlation with Clinical Findings. Journal of Infectious Diseases; 199: 1155-1167.

Sugden K., Moffitt T., Pinto L., Poulton R., Williams B., et al. (2016). Is Toxoplasma gondii Infection Related to Brain and Behavior Impairments in Humans? Evidence from a Population-Representative Birth Cohort. PLoS ONE 11(2); e0148435.

Aseel S., Sabeeha A., Abdul-Kareem A. (2019). PCR detection of Toxoplasma gondii B1 gene in women suffering from abortion. Journal of Biotechnology Research Center; 13(1):12-15.

Wiengcharoen J., Chiabchalard R., Sukthana Y. (2004). PCR technique for detecting Toxoplasma gondii in animal amniotic fluid. The Southeast Asian Journal of Tropical Medicine and Public Health; 35(4):792-5.

Van de Ven E., Melchers W., Galama J., Camps W., Meuwissen J. (1991). Identification of Toxoplasma gondii infections by $B I$ gene amplification. Journal of clinical microbiology; 29(10):2120-2124.

Singh S. (2003). Mother to child transmission and diagnosis of Toxoplasma gondii infection during pregnancy. Indian journal of medical microbiology; 21(2):69-76.
Fatin M., Mohammed A., Rafae Z., Mukhlif S. (2018). Diagnostic study for Toxoplasmosis by Serological test and PCR technique in Kirkuk province, Iraq. Tikrit Journal of Pure Science; 23(1): 19-25.

Badr M., Attia S., El-Sherbiny W., Abd-Allah M., Hefny H., Salem A. (2016). Genetic polymorphism of Toxoplasma gondii from recently infected aborted Egyptian women. Journal of the Egyptian Society of Parasitology; 46(1):49-55.

Mousavi P., Mirhendi H., Mohebali M. (2018). Detection of Toxoplasma gondii in acute and chronic phases of infection in immunocompromised patients and pregnant women with real-time PCR assay using TaqMan fluorescent probe. Iranian Journal of Parasitology; 13(3):373-381.

Naqid I., Yousif S., Hussein N. (2019). Serological study of IgG and IgM Antibodies to Cytomegalovirus and Toxoplasma infections in pregnant women in Zakho City, Kurdistan Region, Iraq. Women's Health Bulletin; 6(4):812.

Manal A., SH Eassa, A.T.M. Al-saeed. (2016). Detection of toxoplasmosis among women with abortion using molecular and serological tests in Duhok city, Iraq. Duhok Medical Journal; 10(2):56-68.

Nash J., Chissel S., Jones J., Warburton F., Verlander N. (2005). Risk factors for toxoplasmosis in pregnant women in Kent, United Kingdom. Epidemiology and Infection; 133(3):475-483.

Sharifi K., Hosseini F., Tara F., Khaledi A., Shamsian S. (2019). Diagnosis of Acute Toxoplasmosis by IgG and IgM Antibodies and IgG Avidity in Pregnant Women from Mashhad, Eastern Iran. Iranian Journal of Parasitology; 14(4):639-645.

Said B., Halsby K., O'connor C., Francis J., Hewitt K., Verlander N., et al. (2017). Risk factors for acute toxoplasmosis in England and Wales. Epidemiology and Infection; 145(1):23-29. 
Scallan E., et al. (2015). An assessment of the human health impact of seven leading foodborne pathogens in the United States using disability-adjusted life years. Epidemiology and Infection; 143(13):2795-2804.

Mangen M., et al. (2015). Cost-of-illness and disease burden of food-related pathogens in the Netherlands, 2011. International Journal of Food Microbiology; 196:84-93.

Fallah M., Rabiee S., Matini M., Taherkhani H. (2008). Seroepidemiology of toxoplasmosis in primigravida women in Hamadan, Islamic Republic of Iran, 2004.The Eastern Mediterranean Health Journal; 14(1):163-71.

Fenta D. (2019). Seroprevalence of Toxoplasma gondii among pregnant women attending antenatal clinics at Hawassa University comprehensive specialized and Yirgalem General Hospitals, in Southern Ethiopia. BMC Infectious Diseases; 19:1056.

Mandour A., Mounib M., Eldeek H., Ahmad A., Abdel-Kader A. (2017). Prevalence of congenital toxoplasmosis in pregnant women with complicated pregnancy outcomes in
Assiut governorate, Egypt. Journal of Advances in Parasitology; 4(1):1-8.

Abamecha F., Awel H. (2016). Seroprevalence and risk factors of Toxoplasma gondii infection in pregnant women following antenatal care at Mizan Aman general hospital, bench Maji zone (BMZ), Ethiopia. BMC Infectious Diseases; 16(1):460.

Bamba S., Cisse M., Sangare I., Zida A., Ouattara S., Guiguemde R. (2017). Seroprevalence and risk factors of Toxoplasma gondii infection in pregnant women from Bobo Dioulasso, Burkina Faso. BMC Infectious Diseases; 17(1):482.

Tlamcan, Z., Lemkhenete Z., Lmimouni B. (2013). Toxoplasmosis: The value of molecular methods in diagnosis compared to conventional methods. Journal of Microbiology and Infectious Diseases; 3(2):93-99.

Al-Dujaily K., Amir N. (2014). Combination of ELISA and RT-PCR tests in the diagnosis of toxoplasmic infection in aborted women and congenitally infected infants. Journal of Biotechnology Research Center; 8(3):44-47. 
دياركرنا نه خوشيا توكسويلازمايـ ل بازيّريّ دهوكى ههريّما كوردستانا عيراقى

يوخته

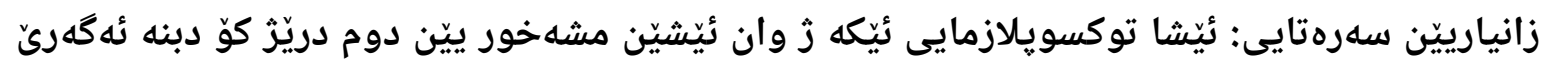

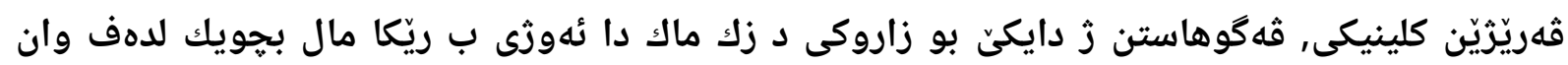

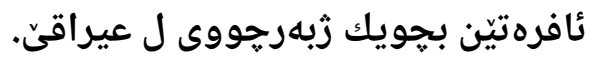

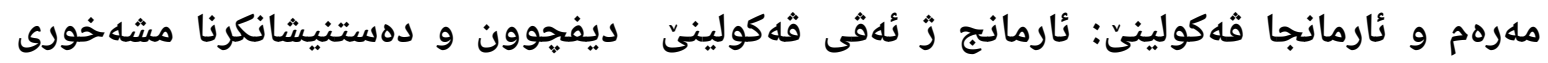

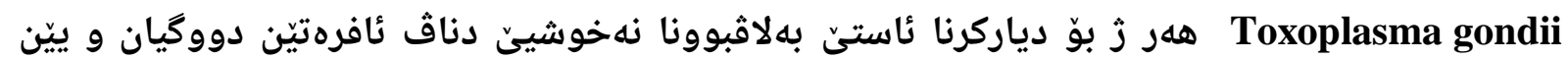

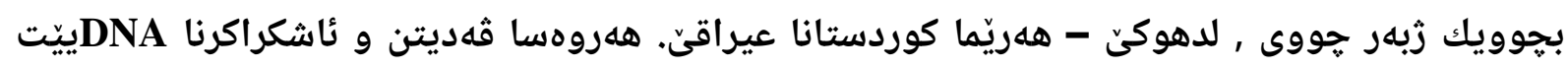
مشهخورى Toxoplasma gondii ز مال بجويك ييّن نهخوشيّن جورا وجور بكارئينانا تهكنيكا تيككاركرن

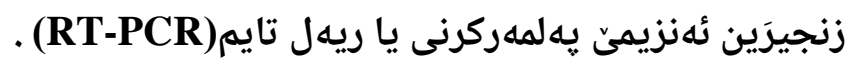
ريّكيّن قهوكولينى:102 نموونه ز وان ئافرهتان هاتنه وهركرتن ئهويّن سهرهدانا نهخوشخانا ئافرهت و و

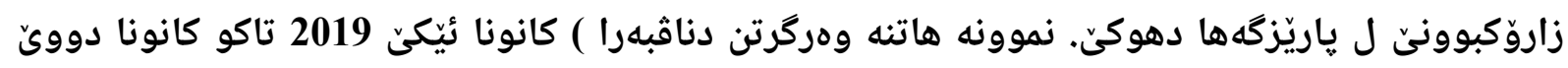

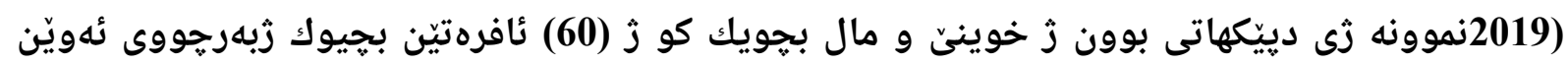

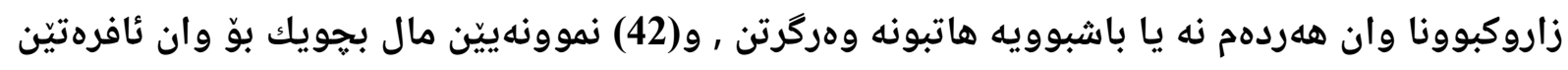

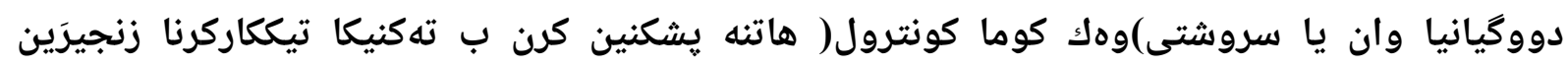

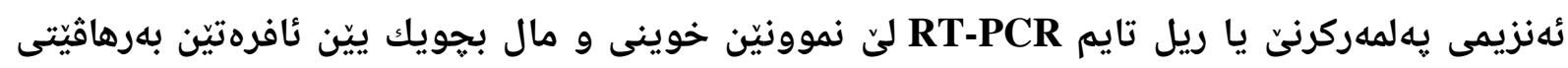

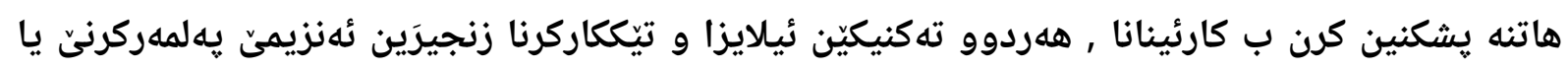
ريهل تايم.

ئهنجام: ئهنجام دياربوون كوّ ريّزا توشبوونيّ ب ئيّشا توكسويلازمايّي يا زلك ماك يا كيّمه, ئانكو بكارئينانا

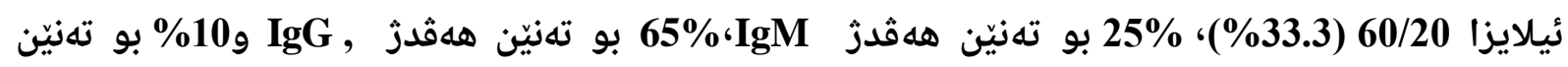

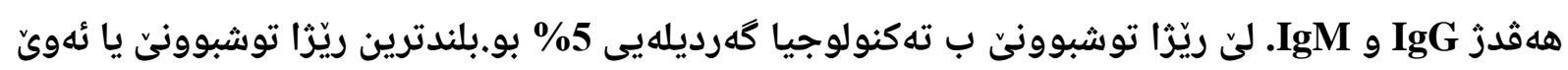

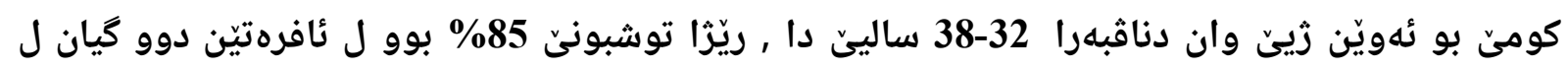

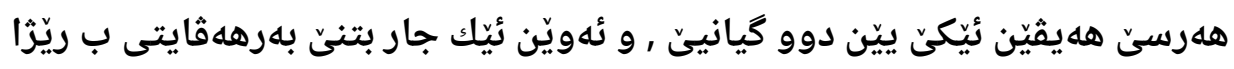

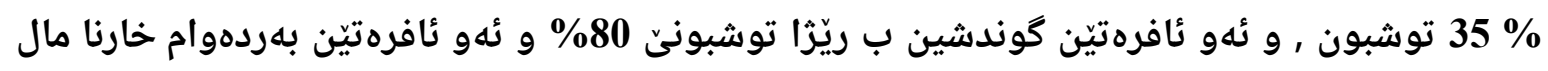

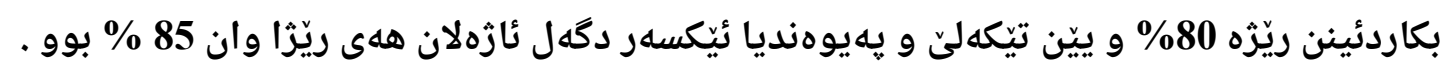

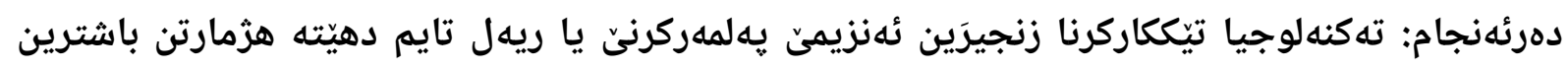

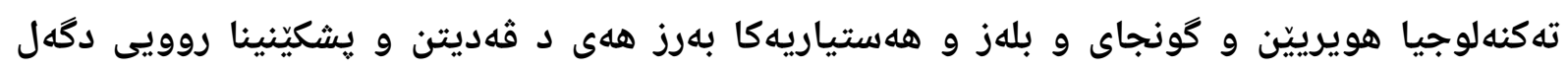

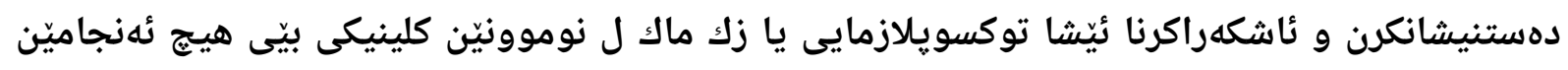

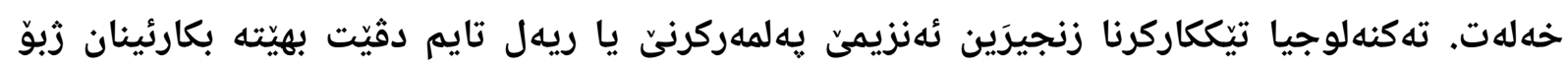

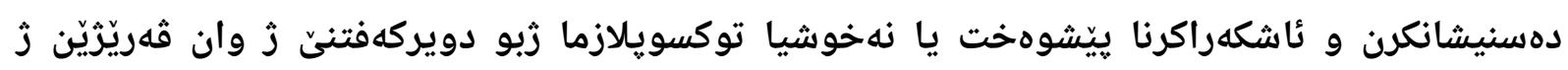

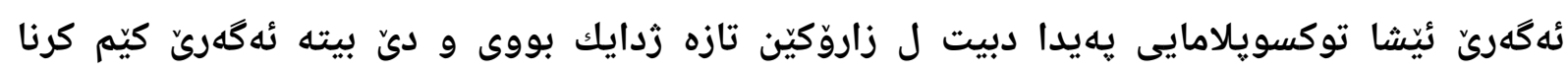
تيّجووييّن جارهسهريا كران بها. 


$$
\text { الكشف عن داء المقوسات بين نساء مدينة دهوك- أقليم كوردستان العراق }
$$

الخلاصة

داء المقوسات هو واحد من اكثر الأمراض الطفيلية المزمنة التي تؤدي الى مضاعفات سريرية عن الطن

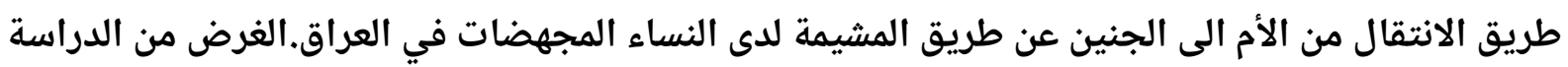
الحالية هو مسح وتشخيص طفيلي Toxoplasma gondii لتقديرانتشار داء المقوسات بين النساء الحوامل والمجهضات في دهوك- أقليم كوردستان العراقواستخلاص والكشف عن الحمض النووي للطفيلي Toxoplasma gondii

$$
\text { الوقت الحقيقي في دهوك- أقليم كوردستان العراق. }
$$

طرق البحث: تم جمع 102 عينة من النساء اللواتي يرتدن مستشفى النسائية والتوليد في محوفئئ محافظة

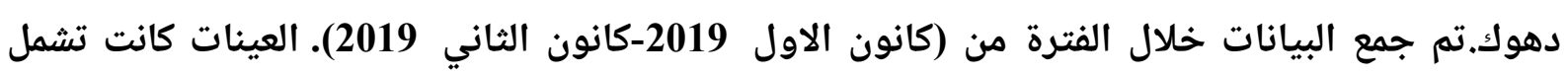
الدم والمشيمة جمعت من 60 أمرأة مجهضة ذات تاريخ ولادي سيء و و 42 عينة مشيمة نساء حوامل

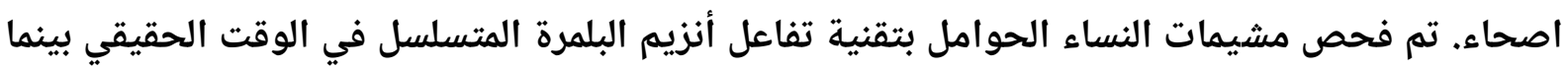

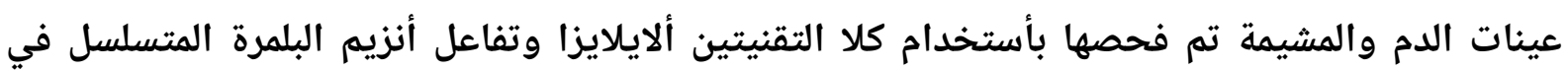
الوقت الحقيقي. T. النتائج: كشفت النتائج عن نسب اصابة منخفضة بداء المقوسات الولادي.الايجابية المصلية لطفيلي gondii كانت 20 (33.3\%) بأستخدام الاليزا. 25\% للجسم المضاد IgM و 65 \% و IgG \%5 \% اعلى نسب الأصابة كانت للمجموعة العمرية 38-32 وفي الاشهر الثلاثة الاولى من الحمل بنسبة

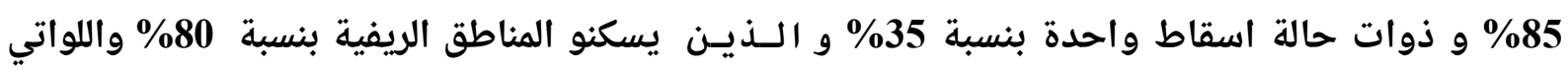

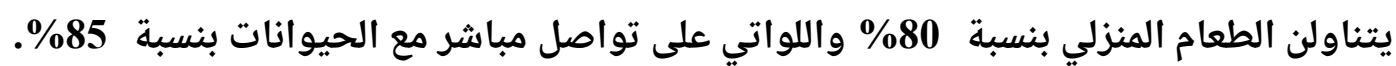
الأستنتاج: تقنية تفاعل أنزيم البلمرة المتسلسل في الوقت الحقيقي هي اكثر تقنية دقيقة ومناسبة وذات

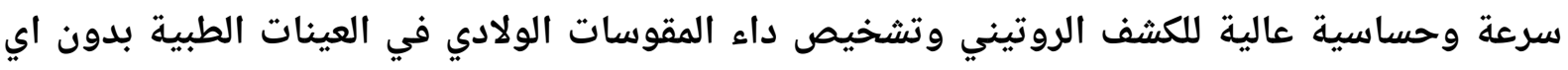
نتائج خاطئة للحصول على العلاج المناسب والكشف المبكر عن الاصابة لتجنب المضاعفات الناتجة عن داء المقوسات التي قد تصيب حديثي الولادة والتي قد تؤدي الى تكاليف باهضة المناسئ للعالاج. 